\title{
An environmental assessment of United States drinking water watersheds
}

\author{
James D. Wickham • Timothy G. Wade • \\ Kurt H. Riitters
}

Received: 4 November 2010/Accepted: 18 February 2011/Published online: 15 March 2011

(C) Springer Science+Business Media B.V. (outside the USA) 2011

\begin{abstract}
There is an emerging recognition that natural lands and their conservation are important elements of a sustainable drinking water infrastructure. We conducted a national, watershed-level environmental assessment of 5,265 drinking water watersheds using data on land cover, hydrography and conservation status. Approximately $78 \%$ of the conterminous United States lies within a drinking water watershed. The typical drinking water watershed had a high percentage of natural vegetation $(\tilde{x}=77 \%)$ but a low percentage of it was set aside for conservation $(\tilde{x}=3 \%)$. Median percentage values for urban and agriculture were 5 and $8 \%$, respectively. Between ca. 1992 and ca. 2001, approximately 23\% of the drinking water watersheds lost at least $1 \%$ of their natural vegetation, and approximately $9 \%$ of the watersheds had at least a $1 \%$ increase in the amount of urban land. Loss of natural vegetation was common in nearly all areas of the country, but also concentrated in
\end{abstract}

Electronic supplementary material The online version of this article (doi:10.1007/s10980-011-9591-5) contains supplementary material, which is available to authorized users.

J. D. Wickham $(\bowtie) \cdot$ T. G. Wade

National Exposure Research Laboratory, U.S.

Environmental Protection Agency, 109 TW Alexander

Drive, Research Triangle Park, NC 27711, USA

e-mail: wickham.james@epa.gov

K. H. Riitters

Southern Research Station, U.S. Forest Service, Research

Triangle Park, NC 27709, USA the Ohio River and Southeast hydrologic regions. Urbanization was concentrated in the eastern United States, primarily in the Mid-Atlantic and Southeast hydrologic regions.

Keywords Conservation - Land-cover change · Land use $\cdot$ Sustainability

\section{Introduction}

There is a growing recognition of the importance of natural land and its conservation for protection of drinking water supplies. A survey of 105 of the world's larger cities revealed that nearly one-third have some form of conservation and protection for at least part of the their drinking water source areas (Dudley and Stolton 2003). In 2009, the U.S. Secretary of Agriculture emphasized the importance of forests and other rural lands for providing the nation's drinking water (Vilsack 2009). Protection of drinking water sources may also reduce the treatment costs. Ernst et al. (2004) reported a nonlinear and inverse relationship between drinking water treatment costs and the percentage of forest in the source watershed. The invigoration of land conservation surrounding New York City's drinking water supply occurred because investment in land conservation was considered more cost effective than investment in additional treatment facilities (NRC 2000). Seattle (WA), Boston (MA), Portland (OR), and other 
smaller cities have also invested in land conservation rather than additional treatment facilities because it was considered to be a more cost-effective means of providing clean drinking water (Postel and Thompson 2005).

Approximately two-thirds of the U.S. population relies on drinking water from surface sources (Levin et al. 2002; U.S. EPA 2008). Protection of drinking water in the United States is administered through the Safe Drinking Water Act (SDWA) (P.L. 104-182), and based on a multiple barrier conceptual model (U.S. EPA 1997; Mehan III 2009; Dougherty 2010). The multiple barrier concept advocates using several defenses to protect drinking water (Hrudey et al. 2006; Mehan III 2009; Plummer et al. 2010). Treatment (filtration, disinfection), monitoring, infrastructure investment (U.S. EPA 2002, 2009) and public outreach (U.S. EPA 1997; Plummer et al. 2010) are used as coordinated elements to ensure the delivery of clean drinking water.

The 1996 Amendments to the SDWA shifted the emphasis of environmental assessment from contaminant detection to source water protection (U.S. EPA 1997; Mehan III 2003). Within the framework of a multiple barrier conceptual model, the new emphasis on source water protection adds management of the land from which drinking water is drawn as another element of a coordinated defense designed to ensure delivery of clean drinking water. Source water protection is one element of a sustainable drinking water infrastructure (Dougherty 2010). New in the 1996 Amendments was a requirement that each state develop source water assessment plans. Source water assessment plans include: (1) delineation of drinking water source areas (i.e., watersheds); (2) inventory of potential contaminants; (3) assessment of susceptibility of drinking water sources to contaminants, and; (4) public dissemination of the assessments. Under the SDWA 1996 amendments, each state submits its source water assessment plan to the U.S. Environmental Protection Agency and updates the assessment periodically. Section 1413 of SDWA authorizes states to assume oversight of its drinking water systems (Tiemann 2010).

Because of the emphasis on individual states, there is no national assessment of drinking water source areas. The objective of this report is to further develop and inform source water protection as an element of a sustainable drinking water infrastructure by conducting a national assessment of drinking water watersheds. The assessment is based on fundamental drivers of water quality including landcover composition, land-cover change, conservation status, and hydrographic context of drinking water watersheds. Land cover is a foundation upon which many environmental assessments, including water quality, are based. Changes in land cover lead to changes in water quality (Wickham et al. 2005; Gilliom et al. 2006), watershed runoff (Ponce and Hawkins 1996), and rainfall patterns (Marshall et al. 2004). Thus, measurements of land-cover composition and change are necessary for understanding environmental condition and issues related to water sustainability (Turner et al. 2007). Conducting the assessment nationally not only helps to integrate the individual state assessments, it also enables the application of a consistent database that can be applied to an individual watershed, a state, a multistate region, and the nation. The nationwide scope also enables examination of regional variation in conditions, which provides useful information about national priorities for environmental management and allocation of resources to improve drinking water sustainability.

\section{Methods}

The U.S. EPA Office of Water provided the surface drinking water intakes as point $(\mathrm{X}, \mathrm{Y})$ coordinates (groundwater sources were not evaluated in this study). Drinking water intakes are pipes in lakes, reservoirs, or streams that draw water from the source and transport it to a water treatment plant (Supplementary material, Fig. S1). The mapped location of each intake was inspected prior to including it in the analyses. Inclusion was based on two criteria. First, intakes that were less than $150 \mathrm{~m}$ upstream of another intake were excluded from the analysis because the upstream watersheds were deemed to be essentially the same as their downstream counterparts. Second, the National Hydrography Dataset (NHD) reach classification (Supplementary material, Table S1) was used to determine if a watershed could be delineated for each intake. Intakes that occurred on the NHD classes "pipeline" and "canal/ditch" were excluded from the analyses. The exclusion of drinking water intakes that did not meet these two criteria 
resulted in 5,265 drinking water intakes for which watersheds could be delineated. The watersheds delineated for these drinking water intakes were combined with land-cover, hydrographic, and protected areas data to conduct the environmental assessment. The watershed delineations and analyses were organized by U.S. Geological Survey hydrologic regions (Fig. 1).

Determining the total land area of the conterminous United States within a drinking water watershed required removal of the inherent nesting of watersheds. Nesting was removed by inspecting all watersheds for the occurrence of smaller, embedded watersheds. The subset of watersheds without smaller, embedded watersheds was used to estimate the amount of land area in the conterminous United States that was within a drinking water watershed.

Location adjustments were necessary for some of the intakes located in lakes and reservoirs because they were not necessarily located where the water body drained to an out-flowing stream. These intakes were moved to the water body outlet so that the delineated watershed included the entire water body. Moving intake locations in lakes and reservoirs to the water body outlet had the potential to change the size of the watershed, and in turn change the total area of the conterminous United States that was within a drinking water watershed. The NHD data were used to gauge the effect of moving intakes in lakes and reservoirs on the total land area of the conterminous
United States that was within a drinking water watershed. If an NHD reach did not enter the water body downstream of the original location of the intake, the intake was moved to the water body outlet, and the watershed for that intake was based on locating the intake at the water body outlet. If an NHD reach entered the water body downstream of the original point location, a complementary point was added at the water body outlet in a separate file, and the original location was used in the main dataset. The watershed sizes for the two locations were then used to determine the effect of moving the intake on the total land area of the conterminous United States that was within a drinking water watershed. Moving intakes in lakes and reservoirs to the water body outlet had a very small effect on the total area of the conterminous United States that was within a drinking water watershed (Supplementary material, Table S2).

The National Land Cover Database (NLCD) 1992-2001 land-cover change data (Fry et al. 2008) were used to estimate land-cover composition and land-cover change within the drinking water watersheds and their near-stream (riparian) environments. The NLCD 1992-2001 land-cover change data provide "from" (ca. 1992) and "to" (ca. 2001) changes in land cover using an eight-class legend (Supplementary material, Table S3). Changes were computed for natural, urban, and water land-cover classes. Natural was defined as the combination of the
Fig. 1 USGS hydrologic regions overlaid on state boundaries. Names for each region number are provided in Table 1 of the main article

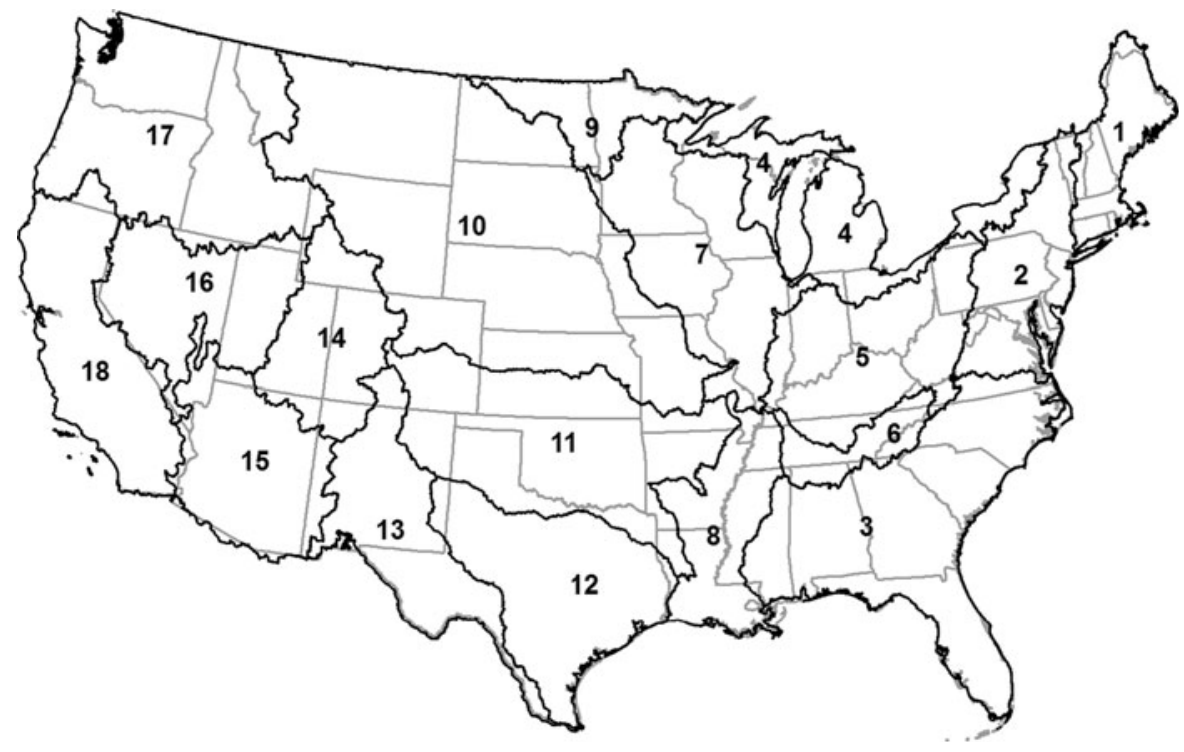


forest, shrubland-grassland, and wetland classes. Change computations were formulated as values for 2001 minus values for 1992 so that losses were negative and gains were positive. The percentages changes that we report are based on watershed area.

For the riparian analysis, the near-stream width was set to a $120 \mathrm{~m}$ radius. Several high resolution $(1: 24,000)$ NHD datasets were conflated to define the near-stream environment. The conflation included NHD datasets that represented water bodies (lakes and reservoirs), large rivers, and smaller rivers and streams. By combining these datasets the near-stream environment included the shoreline of lakes and reservoirs and treated large rivers as having two banks.

We used the Protected Areas Database to estimate the amount of land set aside for conservation (DellaSala et al. 2001). The Protected Areas Database includes two primary attributes for conservation and land management. These are the International Union for Conservation of Nature (IUCN) codes and the Gap Analysis Program (GAP) (Scott et al. 1993) land stewardship codes (Supplementary material, Table S4). Our analysis included all lands with a GAP stewardship code of three or less. Lands identified with a GAP stewardship code of three or less includes all lands with IUCN codes one through six. We relied or the GAP stewardship codes rather than the IUCN codes because many lands with GAP stewardship codes of one and two did not have an associated IUCN code. Some protected lands would have been omitted if we had used IUCN codes to derive our conserved lands dataset. Our estimate of the total protected area was 209,459,669 ha, which was approximately $27 \%$ of the total area of the conterminous United States (Supplementary material, Table S5). Lands with a GAP stewardship code of three comprised approximately $75 \%$ of the $209,459,669$ ha of protected area. U.S. National Forests, lands managed by the Bureau of Land Management (BLM) and U.S. military reservations were commonly assigned a GAP stewardship code of three.

\section{Results}

Approximately $78 \%$ of the conterminous United States lies within a drinking water watershed (Table 1). The proportion of land within a drinking water watershed varies regionally, from a low of
$2.7 \%$ in the Great Basin region to $100 \%$ for many of the mid-continent and western regions. The typically high proportion of the land area of the conterminous United States within drinking water watersheds reflects the fact that most of the major rivers are used to supply drinking water (InsideEPA.com 2010) even though drinking water drawn from rivers is often more polluted and more expensive to treat than water drawn from lakes and reservoirs (Gray 2008). We found that approximately two-thirds of all the surface drinking water intakes in the conterminous United States are in rivers and one-third are in lakes and reservoirs.

The majority of drinking water watersheds are dominated by natural vegetation (Fig. 2). The median percentage natural vegetation is $77.1 \%$, varying geographically from $17.1 \%$ in the upper Mississippi region to more than $90 \%$ for the western United States (Table 2). While drinking water watersheds are generally comprised of a high percentage of natural vegetation, the amount of land set aside for conservation is small. One-half of the drinking water watersheds have less than $3.1 \%$ of their area set aside for conservation (i.e., protected). The much higher percentage protection in the western United States is attributable to high percentages of land in federal ownership (primarily the U.S. Forest Service and U.S. Bureau of Land Management). The high median percentage of natural vegetation in drinking water watersheds translates to relatively low median percentages for urban $(\tilde{x}=5.2 \%)$ and agriculture $(\tilde{x}=8.1 \%)$ (Table 2). Comparing the median values for urban and agriculture with the median protected value indicates that the typical drinking water watershed has approximately $67 \%$ more urbanized land and $160 \%$ more agricultural land than land set aside in conservation. Land-cover composition and the amount of conserved land change with watershed size, approaching the national estimates for the respective statistics for the largest watersheds (Supplementary material, Table S5) (Homer et al. 2007).

The land-cover composition and conserved land analyses were also conducted for the near-stream (riparian) environment because riparian management and restoration are activities supported by state and federal policies (Sweeney et al. 2004). In the case of drinking water, riparian areas are one example of sensitive source areas (Plummer et al. 2010), and watershed delineation based on pollutant travel time is 
Table 1 Area of U.S. drinking water watersheds by U.S. Geological Survey hydrologic regions

\begin{tabular}{|c|c|c|c|c|}
\hline Region & Name & Drinking water watershed area (ha) & Area of Region (ha) & Percentage $(\%)$ \\
\hline 1 & New England & $5,745,791$ & $15,544,971$ & 37.0 \\
\hline 2 & Mid-Atlantic & $22,172,165$ & $27,171,609$ & 81.6 \\
\hline 3 & Southeast & $30,831,906$ & $69,181,029$ & 44.6 \\
\hline 4 & Great Lakes & $7,282,712$ & $30,280,901$ & 24.1 \\
\hline 5 & Ohio & $42,194,511$ & $42,194,511$ & 100.0 \\
\hline 6 & Tennessee River & $10,595,378$ & $10,595,378$ & 100.0 \\
\hline 7 & Upper Mississippi & $49,177,325$ & $49,177,325$ & 100.0 \\
\hline 8 & Lower Mississippi & $20,811,766$ & $25,916,411$ & 80.3 \\
\hline 9 & Souris-Red-Rainy & $10,319,496$ & $15,704,309$ & 65.7 \\
\hline 10 & Missouri & $132,225,308$ & $132,225,308$ & 100.0 \\
\hline 11 & Arkansas-White-Red & $64,238,408$ & $64,238,408$ & 100.0 \\
\hline 12 & Texas Gulf & $36,355,684$ & $46,299,359$ & 78.5 \\
\hline 13 & Rio Grande & $32,588,683$ & $33,897,488$ & 96.1 \\
\hline 14 & Upper Colorado & $29,357,007$ & $29,357,007$ & 100.0 \\
\hline 15 & Lower Colorado & $35,063,208$ & $35,063,208$ & 100.0 \\
\hline 16 & Great Basin & 980,850 & $36,731,499$ & 2.7 \\
\hline 17 & Pacific Northwest & $63,950,968$ & $70,846,826$ & 90.3 \\
\hline 18 & California & $13,742,548$ & $41,452,336$ & 33.2 \\
\hline All & Conterminous U.S. & $607,633,714$ & $775,877,883$ & 78.3 \\
\hline
\end{tabular}

Regions $5,6,7,10,11$, and 14 are upstream of region 8 and 15 so the total drinking water watershed area in the upstream regions is equal to the area of the region (i.e., 100\%). Area estimates for hydrologic regions were based on the USGS hydrologic region map (Fig. 1) adjusted to state boundaries, and exclusive of major water bodies (e.g., Great Lakes)

essentially the near-stream environment. Median values for the riparian environment were very similar to the watershed median values despite a few noticeable differences in some regions (Table 2). These results are not unexpected because of the commonly strong correlation between riparian and watershed land-cover characteristics (Van Sickle 2003).

Natural vegetation in the drinking water watersheds was temporally dynamic between ca. 1992 and ca. 2001. Approximately $23 \%$ of the watersheds $(1,200$ of $5,265)$ lost at least $1 \%$ of their natural vegetation, and approximately $5 \%$ of the watersheds had at least a $1 \%$ increase in natural vegetation. The corresponding statistics for the riparian area were $21 \%$ (at least a $1 \%$ loss) and $6 \%$ (at least a $1 \%$ gain). Loss of natural vegetation in drinking water watersheds was spread throughout the country but also showed some geographic concentration. At least $8 \%$ of the drinking water watersheds in 16 of the 18 hydrographic regions lost at least $1 \%$ of their natural vegetation, with only the Souris-Red-Rainy and Rio Grande hydrologic regions not reaching the $8 \%$ threshold. Overlaid on the nationwide pattern was a concentration of natural vegetation loss in the Southeast and Ohio hydrologic regions; $42 \%$ of the watersheds with at least a $1 \%$ loss of natural vegetation occurred in these two hydrologic regions (Fig. 3). Gains in natural vegetation were concentrated in four mid-continent (Ohio, Missouri, Arkansas-White-Red, Texas Gulf) and the Mid-Atlantic hydrographic regions. The gains in natural vegetation in these regions were predominantly agricultural abandonment giving way to shrublands.

Much of the loss of natural vegetation was attributable to urbanization. Approximately $9 \%$ of the drinking water watersheds had at least a $1 \%$ increase in urban land between ca. 1992 and ca. 2001. Urbanization was greatest in the eastern United States. Approximately one-half of the drinking water watersheds with at least a $1 \%$ increase in urbanization were in the Mid-Atlantic and Southeast hydrographic regions (Fig. 4). The highest percentage increases in urban land were not strictly confined to smaller watersheds, indicating urbanization was widespread in some larger watersheds. We also found that the 
Fig. 2 Cumulative distributions of natural vegetation (a), agriculture (b), and urban (c) for 5,265 drinking water watersheds
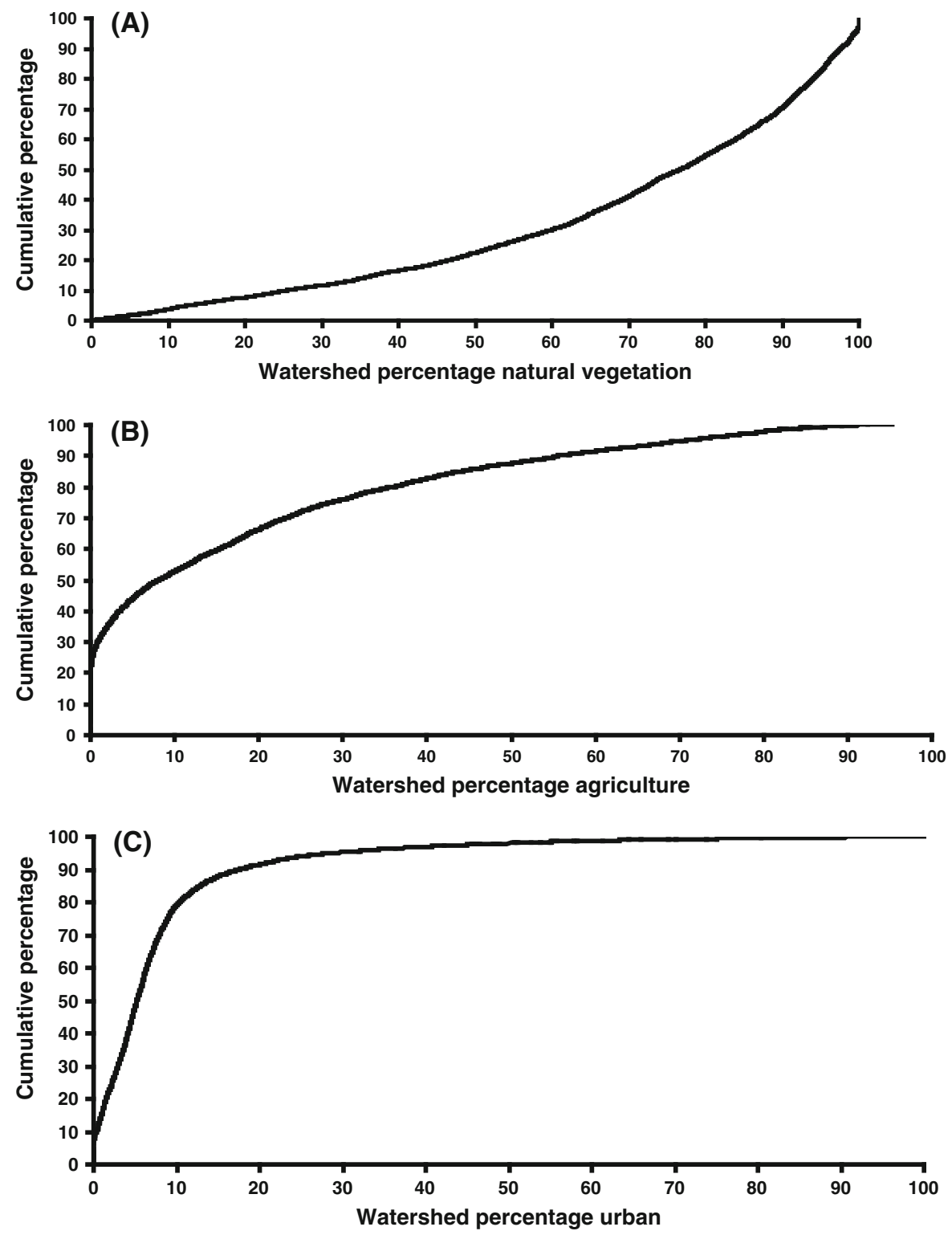

amount of urban land increased in $75 \%$ of the drinking water watersheds.

\section{Discussion}

The multiple barrier defense is a non-probabilistic risk management model used to protect U.S. drinking water resources. The multiple barrier defense assumes that the likelihood of delivering contaminated drinking water is reduced if natural vegetation is maintained and conserved, treatment of raw (e.g., river, lake) water is adequate and consistent, the delivery system is kept in a state of good repair, and there is effective communication with the public. The 1996 amendments to the Safe Drinking Water Act advanced the multiple barrier conceptual model through its requirement that states delineate source water watersheds to serve as the basis for the inventory of potential pollutants, assessment of the susceptibility of drinking water to contamination by pollutants, and public outreach (U.S. EPA 1997). The 1996 amendments established drinking water watersheds as the framework upon which drinking water is managed. 
Table 2 Median values of percentage conserved land, natural vegetation, urban, and agriculture for drinking water watersheds and the near-stream (riparian) environment from ca. 2001 NLCD

\begin{tabular}{|c|c|c|c|c|c|c|c|c|c|}
\hline \multirow[t]{2}{*}{ Region } & \multirow{2}{*}{$\begin{array}{l}\text { Number of } \\
\text { Watersheds }\end{array}$} & \multicolumn{2}{|c|}{ Conserved Land } & \multicolumn{2}{|c|}{ Natural Vegetation } & \multicolumn{2}{|l|}{ Urban } & \multicolumn{2}{|l|}{ Agriculture } \\
\hline & & $\begin{array}{l}\text { Watershed } \\
(\%)\end{array}$ & $\begin{array}{l}\text { Riparian } \\
(\%)\end{array}$ & $\begin{array}{l}\text { Watershed } \\
(\%)\end{array}$ & $\begin{array}{l}\text { Riparian } \\
(\%)\end{array}$ & $\begin{array}{l}\text { Watershed } \\
(\%)\end{array}$ & $\begin{array}{l}\text { Riparian } \\
(\%)\end{array}$ & $\begin{array}{l}\text { Watershed } \\
(\%)\end{array}$ & $\begin{array}{l}\text { Riparian } \\
(\%)\end{array}$ \\
\hline 1 & 474 & 2.7 & 1.3 & 78.7 & 74.9 & 6.2 & 6.3 & 3.1 & 2.7 \\
\hline 2 & 816 & 4.8 & 2.1 & 77.6 & 73.1 & 4.9 & 5.6 & 8.6 & 6.2 \\
\hline 3 & 489 & 0.2 & 0.2 & 65.4 & 70.9 & 9.0 & 6.5 & 17.5 & 14.4 \\
\hline 4 & 164 & 0.8 & 0.4 & 35.5 & 43.7 & 6.5 & 7.2 & 39.9 & 35.3 \\
\hline 5 & 707 & 1.8 & 2.0 & 69.4 & 69.9 & 6.7 & 7.3 & 20.1 & 17.5 \\
\hline 6 & 208 & 7.3 & 6.7 & 70.3 & 68.3 & 6.8 & 7.5 & 18.5 & 19.4 \\
\hline 7 & 144 & 0.0 & 0.0 & 17.6 & 30.5 & 7.1 & 6.6 & 68.6 & 53.9 \\
\hline 8 & 52 & 11.4 & 13.4 & 58.8 & 64.1 & 5.3 & 4.6 & 22.4 & 28.6 \\
\hline 9 & 21 & 3.2 & 3.0 & 22.1 & 30.2 & 4.4 & 4.3 & 68.8 & 56.1 \\
\hline 10 & 399 & 14.8 & 17.7 & 67.2 & 72.1 & 3.3 & 2.6 & 23.2 & 12.3 \\
\hline 11 & 413 & 0.9 & 1.0 & 70.6 & 73.8 & 4.6 & 4.0 & 18.8 & 15.8 \\
\hline 12 & 265 & 0.0 & 0.0 & 80.3 & 86.3 & 4.3 & 3.5 & 13.7 & 6.4 \\
\hline 13 & 43 & 33.9 & 36.1 & 95.6 & 97.4 & 1.3 & 1.0 & 1.4 & 0.6 \\
\hline 14 & 137 & 80.3 & 79.0 & 91.4 & 92.2 & 0.4 & 0.4 & 0.3 & 0.4 \\
\hline 15 & 71 & 85.7 & 79.0 & 96.5 & 96.5 & 1.1 & 1.1 & 0.0 & 0.0 \\
\hline 16 & 58 & 61.7 & 65.7 & 92.4 & 93.2 & 1.9 & 2.9 & 0.0 & 0.0 \\
\hline 17 & 368 & 44.3 & 49.6 & 93.9 & 94.1 & 2.1 & 2.0 & 0.0 & 0.0 \\
\hline 18 & 436 & 17.3 & 28.3 & 93.1 & 93.0 & 3.6 & 3.6 & 0.0 & 0.0 \\
\hline U.S. & 5265 & 3.1 & 3.4 & 77.1 & 77.3 & 5.2 & 4.8 & 8.1 & 6.3 \\
\hline
\end{tabular}

In a probabilistic risk assessment, watershed landcover composition, the amount of conserved land, and hydrographic context would be elements of exposure characterization (Suter et al. 2003). Nitrate, pesticides, industrial chemicals, pathogens, and algal toxins are all potential drinking water contaminants that are attributable to watershed land uses such as urban and agriculture (Gray 2005). For example, urban and agricultural land often contribute excess nitrate to water bodies (e.g., Frink 1991; Wickham et al. 2005). High nitrate levels in drinking water may be hazardous to young children, children with gastroenteritis, and pregnant women (Gray 2005), and may be a risk factor for some cancers (Swartz et al. 2003; Ward et al. 2005). It is also costly and difficult to remove nitrate from drinking water supplies (Gray 2005). Gilliom et al. (2006) found that pesticides occurred at detectable levels year round in streams draining from agricultural and urban areas, and that $5-10 \%$ of the streams in these areas had pesticide concentrations the exceeded humanhealth thresholds. Atrazine, the most commonly detected pesticide (Kolpin et al. 1998; Gilliom et al. 2006), is considered an endocrine disrupting compound that has been attributed to reproductive abnormalities in amphibians and fish (Suzawa and Ingraham 2008). Reynolds et al. (2008) estimated that 183 disease outbreaks were due to pathogen contamination of drinking water between 1991 and 2002. Agricultural and urban land are both significant sources of bacterial contamination of surface waters (Baxter-Potter and Gilliland 1998; Wickham et al. 2006). Toxigenic strains of Escherichia coli, Giardia lamblia, and Cryptosporidium parvum are pathogens of primary concern in the U.S. because they cause dysentery and have also been linked to other diseases (Reynolds et al. 2008).

Although studies are limited, there is evidence directly linking drinking water quality to land-cover composition of the source areas. Hrudey et al. (2006) found that land use factored into drinking water contamination in four of six cases examined. Swartz et al. (2003) found a positive relationship between the amount of residential land use and drinking water 
Fig. 3 Change in natural vegetation ca. 1992 to ca. 2001 for the entire watershed (a) and the riparian area (b). Regions 3 and 5 , are symbolized as red dots and blue dots, respectively. All other regions are symbolized as a plus sign. Watershed area (ha) was converted using a $\log _{10}$ base. (Color figure online)
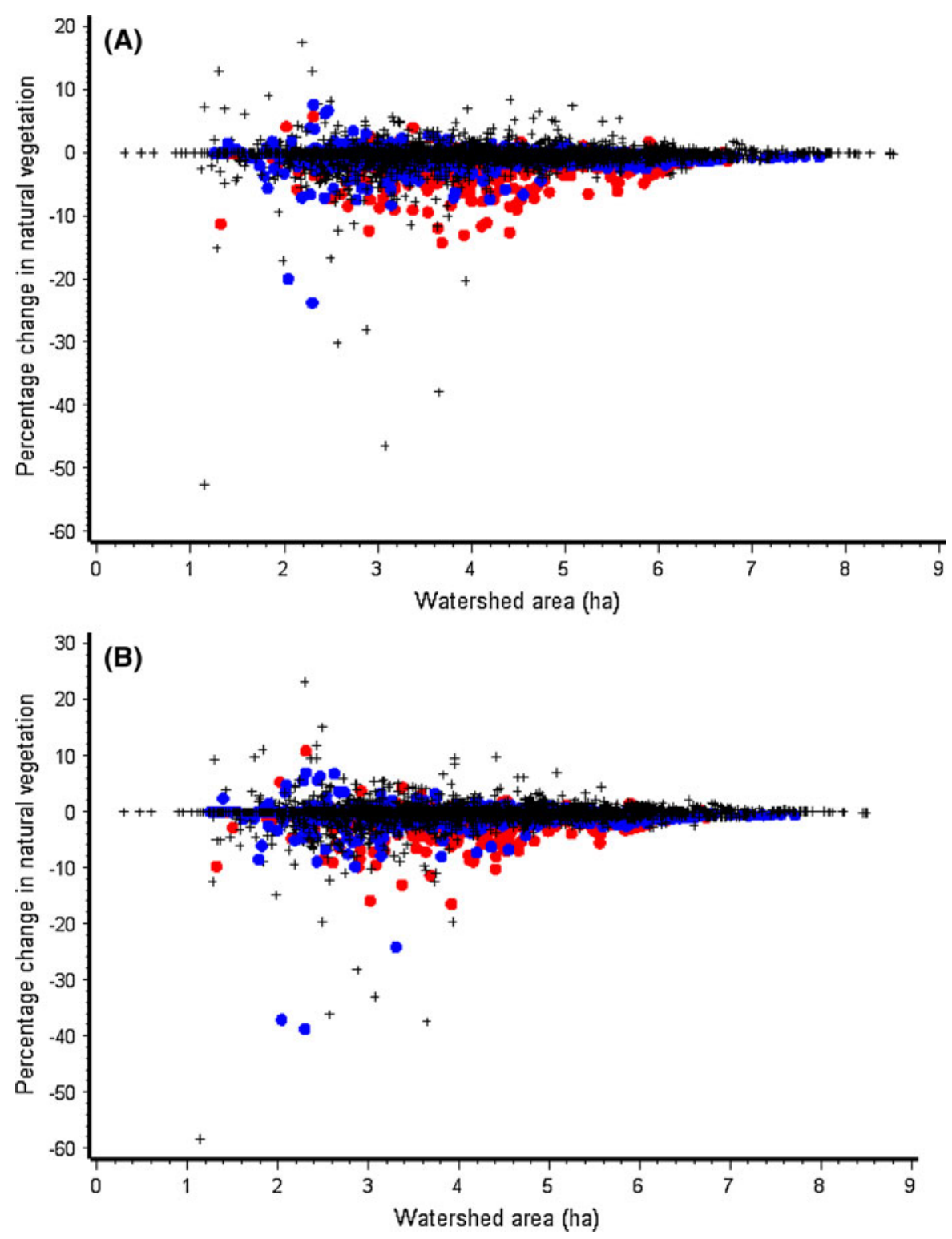

nitrate concentration. Derlet et al. (2010) proposed changes to the cattle grazing system in the Sierra Nevada Mountains as a means to further protect drinking water drawn from the area. Mehaffey et al. (2005) showed that small decreases in urban and agricultural land in the drinking water watersheds for New York City led to detectable improvements in water quality.

The linkage between land-cover composition and drinking water quality emphasizes the importance of natural vegetation for the protection of drinking water source areas (e.g., www.forest-to-faucet.org/ publications.html). Our national analysis showed that most U.S. drinking water watersheds have a high proportion of natural vegetation. This pattern suggests that exposure to drinking water contaminants are likely to be greater in the relatively few watersheds where natural vegetation is not dominant. For example, approximately $20 \%$ of the watersheds $(1,144$ of 5,265$)$ have less than $50 \%$ natural vegetation, and approximately $8 \%$ of the watersheds (411 of 5,265 ) have at least $20 \%$ urbanized land. Our analysis also showed that the dominant temporal trend in landcover composition is loss of natural vegetation and an 
Fig. 4 Change in urban land ca. 1992 to ca. 2001 for the entire watershed (a) and riparian area (b) versus watershed size. Regions 2 and 3 are symbolized as blue dots and red dots, respectively. All other regions are symbolized as a plus sign. Watershed area (ha) was converted using a $\log _{10}$ base. (Color figure online)
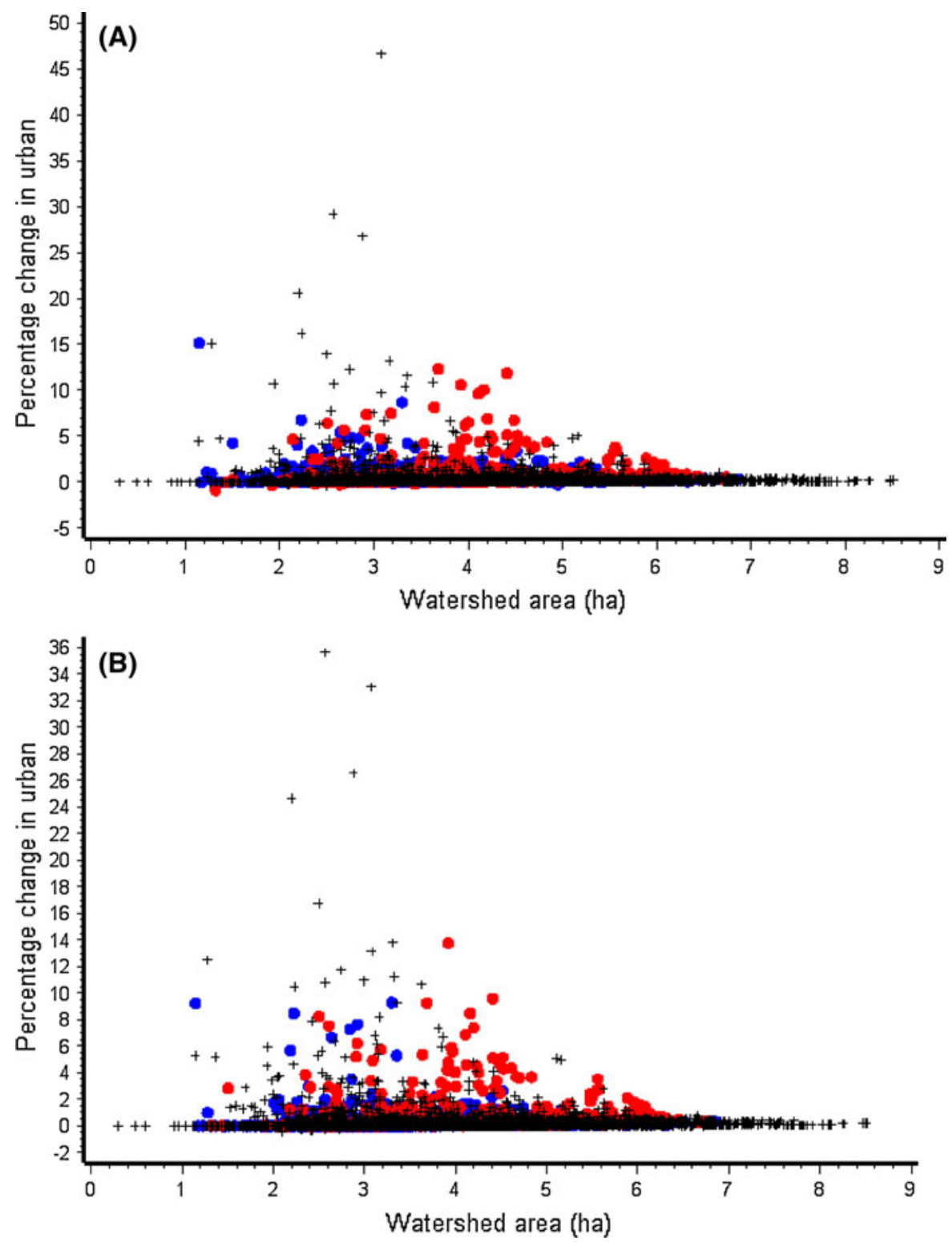

increase in urbanized land. The number of watersheds that lost at least $1 \%$ natural vegetation (1200) was approximately five times greater than the number of watersheds that gained at least $1 \%$ natural vegetation (244), and 9\% of the watersheds (467) had a least a $1 \%$ gain in urbanized land. To the extent that land cover contributes to environmental exposure, recent trends suggest that many drinking water source areas are becoming more exposed to contaminants and pollutants.

There is no doubt that urbanization and consequent loss of natural vegetation are motivating public and scientific interest in conservation for protection of drinking water sources, but the value of conservation has only recently become a focus of drinking water protection (NRC 2000; Dudley and Stolton 2003; Ernst et al. 2004; Postel and Thompson 2005; Mehan III 2009). The interest in land conservation has been mainly within the realm of biodiversity conservation (DellaSala et al. 2001; Scott et al. 2001). The amount of protected land needed to sustain biotic populations has been studied and debated by conservation biologists (Scott et al. 2001; Shaffer et al. 2002), but similar, more broadly scoped discussions have not yet 
occurred with regard to source water protection. The available surveys of land conservation for drinking water protection (e.g., Dudley and Stolton 2003; Postel and Thompson 2005) indicate that conservation occurs on a case-by-case basis, such as New York City (NRC 2000). We found that the median percentage of conserved land in drinking water watersheds for the nation was low $(\sim 3 \%)$, and varied widely from region to region. Median percentages of conserved land were high in the western United States because of the extensive holdings of federal land but quite low in the eastern United States, often less than $1 \%$. Those percentages are relatively low in comparison to the International Union for the Conservation of Nature and Natural Resources threshold of $12 \%$ for adequate protection of biological and genetic diversity of a plant community (Miller 1984).

Our analysis shows the value of a national perspective in the assessment of drinking water resources. National assessments provide a level of integration and insight (Riitters et al. 2002; Riitters and Wickham 2003; The Heinz Center 2008; Wickham et al. 2008, 2010) that can complement stateadministered management of drinking water source areas (Tiemann 2010; ASDWA 2009). Nationally, over three-quarters of the conterminous United States lies within a drinking water watershed, and many of them cross state boundaries. There was strong regional variation in the amount of natural vegetation, urban and agricultural land use, and the proportion of land set aside in conservation. There was also distinct regional variation in temporal change in natural vegetation and urbanization. The observed regional patterns in land-cover composition and land-cover change suggest regional and temporal patterns in exposure to drinking water contaminants that merit additional investigation.

Ever-increasing human populations translate into land use pressures that will challenge U.S. drinking water systems in the next century, and responding to the challenge require the coordinated actions of all those sharing watersheds or aquifers (sensu Levin et al. 2002). Our quantitative assessment of landcover patterns for U.S. drinking water watersheds generally substantiates the assessment of Levin et al. (2002). U.S. drinking water watersheds tend to have a high proportion of natural vegetation, but little of it is set aside for conservation, and the dominant trend in land-cover composition is loss of natural vegetation and gain in urban land. These findings suggest that the status of source water protection will change as a result of ineluctable changes in natural vegetation and that the rate of urbanization will likely outpace the rate of new lands set aside in conservation (Scott et al. 2001; Raleigh News \& Observer 2010).

Acknowledgments The paper has been subject to U.S. EPA Office of Research and Development peer and administrative review and approved for publication. The authors thank David Bradford, Ric Lopez, Drew Gronewold, David Holland, and Roger Anzzolin for their comments on earlier drafts.

\section{References}

Association of State Drinking Water Administrators (ASDWA) (2009) National analysis of state drinking water programs in the areas of water availability, variability, and sustainability (WAVS). Available from http://www.asdwa. org/. Accessed February 2011

Baxter-Potter WA, Gilliland MW (1998) Bacterial pollution from agricultural lands. J Environ Qual 17:27-34

DellaSala DA, Stauss NL, Strittholt JR, Hackman A, Iacobelli A (2001) An updated protected areas database for the United States and Canada. Nat Area J 21:124-135

Derlet RW, Goldman CR, Connor MJ (2010) Reducing the impact of summer cattle grazing on water quality in the Sierra Nevada Mountains of California: a proposal. J Water Health 8:326-333

Dougherty C (2010) Water infrastructure: opportunities and challenges for a new decade. J Am Water Works Assoc April:18,20

Dudley N, Stolton S (2003) Running pure: the importance of forest protected areas to drinking water. World Bank/ World Wildlife Fund International. www.worldbank.org

Ernst C, Gullick R, Nixon K (2004) Protecting the source: conserving forests to protect water. Opflow 30:1-7

Frink CR (1991) Estimating nutrient export to estuaries. J Environ Qual 20:717-724

Fry JA, Coan MJ, Homer CG, Meyer DK, Wickham JD (2008) Completion of the National Land Cover Database (NLCD) 1992-2001 land cover change retrofit product. U.S. Geological Survey Open-File Report 2008-1379, Denver CO. Available from http://pubs.usgs.gov/of/2008/ 1379. Accessed February 2011

Gilliom RJ, Barbash JE, Crawford CG, Hamilton PA, Martin JD, Nakagaki N, Nowell LH, Scott JC, Stackelburg PE, Thelin GP, Wolock DM (2006) The quality of our nations waters-pesticides in the nations streams and ground water, 1992-2001. U.S. Geological Survey, Circular 1291, Reston, VA, USA. http://pubs.usgs.gov/circ/2005/ 1291/. Accessed February 2011

Gray NF (2005) Water technology: an introduction for environmental scientists and engineers. Elsevier ButterworkHeinemann, Oxford 
Gray NF (2008) Drinking water quality: problems and solutions, 2nd edn. Cambridge University Press, New York

Homer C, Dewitz J, Fry J, Coan M, Hossain N, Larson C, Herold N, McKerrow A, Van Driel JN, Wickham J (2007) Completion of the 2001 national land cover database for the conterminous United States. Photogramm Eng Rem Sens 73:337-341

Hrudey SE, Hrudey EJ, Pollard ST (2006) Risk Management for assuring safe drinking water. Environ Int 32:948-957

InsideEPA.com (2010) EPA seeks to tally drinking water costs to justify strict nutrient controls. Available from http:// insideepa.com/201008021916123/EPA-Daily-News/DailyNews/epa-seeks-to-tally-drinking-water-costs-to-justifystrict-nutrient-controls/menu-id-95.html. Accessed February 2011

Kolpin DW, Barbash JE, Gilliom RJ (1998) Occurrence of pesticides in shallow groundwater of the United States: initial results from the National Water-Quality Assessment Program. Environ Sci Technol 32:558-566

Levin RB, Epstein PR, Ford TE, Harrington W, Olson E, Reichard EG (2002) U.S. drinking water challenges for the twenty-first century. Environ Health Persp 110(Suppl 1):43-52

Marshall CH, Pielke RA Sr, Steyaert LT, Wallard DA (2004) The impact of anthropogenic land-cover change on the Florida peninsula sea breezes and warm season sensible weather. Mon Weather Rev 132:28-52

Mehaffey MH, Nash MS, Wade TG, Ebert DW, Jones KB, Rager A (2005) Linking land cover and water quality in New York City's water supply watersheds. Environ Monit Assess 107:29-44

Mehan GT III (2003) Director, EPA Office of Water, Memorandum to EPA Regional Administrators

Mehan GT III (2009) Testimony before the Subcommittee on Water Resources and Environment of the House Committee on Transportation and Infrastructure on Sustainable WasteWater Management. Available from http://republicans. transportation.house.gov/Media/File/TestimonyWater/200902-04-Meehan.pdf. Accessed February 2011

Miller KR (1984) The natural protected areas of the world. In: McNeely JA, Miller KR (eds) National parks, conservation, and development. Smithsonian Institution Press, Washington, pp 20-33

National Hydrography Dataset (NHD). Available from http:// nhd.usgs.gov, http://www.horizon-systems.com/nhdplus. Accessed February 2011

National Research Council (NRC) (2000) Watershed management for potable water supply: assessing the New York City strategy. National Academy Press, Washington

Plummer R, Velaniškis J, de Grosbois D, Kreutzwiser RD, de Loë R (2010) The development of new environmental policies and processes in response to a crisis: the case of the multiple barrier approach for safe drinking water. Environ Sci Policy 13:535-548

Ponce VM, Hawkins RH (1996) Runoff curve number: has it reached maturity? J Hydrol Eng 1:11-19

Postel SL, Thompson BH Jr (2005) Watershed protection: capturing the benefits of nature's water supply services. Nat Resour Forum 29:98-108

Raleigh News \& Observer (2010) Land deal to aid Everglades. August 13, Section A, p 3
Reynolds KA, Mena KD, Gerba CP (2008) Risk of waterborne illness via drinking water in the United States. Rev Environ Contam Toxicol 192:117-158

Riitters KH, Wickham JD (2003) How far to the nearest road? Front Ecol Environ 1:125-129

Riitters KH, Wickham JD, O'Neill RV, Jones KB, Smith ER, Coulston JW, Wade TG, Smith JH (2002) Fragmentation of continental United States forests. Ecosystems 5:815-822

Scott JM, Davis F, Csuti B, Noss R, Butterfield B, Groves C, Anderson H, Caicco S, D’Erchia F, Edwards TC Jr, Ulliman J, Wright RG (1993) Gap Analysis: a geographic approach to protection of biological diversity. Wildl Monogr 123:3-41

Scott JM, Davis FW, McGhie RG, Wright RG, Groves C, Estes J (2001) Nature reserves: do they capture the full range of America's biological diversity? Ecol Appl 11:999-1007

Shaffer ML, Scott JM, Casey F (2002) Noah's options: initial cost estimates of a national system of habitat conservation areas in the United States. Bioscience 52:439-443

Suter II GW, Norton SB, Barnthouse LW (2003) The evolution of frameworks for ecological risk assessment from the red book ancestor. Human Ecol Risk Assess 9:1349-1360

Suzawa M, Ingraham HA (2008) The herbicide atrazine activates endocrine gene networks via non-steroidal NR5A nuclear receptors in fish and mammalian cells. PLoS ONE 3(5):e2117. doi:10.1371/journal.pone.0002117

Swartz CH, Rudel RA, Kachajian JR, Brody JG (2003) Historical reconstruction of wastewater and land use impacts to groundwater used for public drinking water: exposure assessment using chemical data and GIS. J Expo Anal Environ Epidemiol 13:403-416

Sweeney BW, Bott TL, Jackson JK, Kaplan LA, Newbold JD, Standley LJ, Hession WC, Horwitz RJ (2004) Riparian deforestation, stream narrowing, and loss of stream ecosystem services. Proc Natl Acad Sci USA 101:1413214137

The Heinz Center (2008) The State of the Nation's Ecosystems 2008: measuring the lands waters and living resources of the United States. Island Press, Washington

Tiemann M (2010) Safe Drinking Water Act (SDWA): a summary of the act and its major requirements. Congressional Research Service, CRS Report to Congress, Order Code RL31243, Washington

Turner BL II, Lambin EF, Reenberg A (2007) The emergence of land change science for global environmental change and sustainability. Proc Natl Acad Sci USA 104:20666-20671

U.S. Environmental Protection Agency (U.S. EPA) (1997) State source water assessment and protection program: final guidance, EPA 816-R-97-009. U.S. EPA Office of Water, Washington

U.S. Environmental Protection Agency (U.S. EPA) (2002) The clean water and drinking water infrastructure gap analysis, EPA-816-R-02-020. U.S. EPA Office of Water, Washington

U.S. Environmental Protection Agency (U.S. EPA) (2008) Factoids: drinking water and ground water statistics for 2008, EPA 816-K-08-004. U.S. EPA Office of Water, Washington

U.S. Environmental Protection Agency (U.S. EPA) (2009) Drinking water infrastructure needs survey and assessment: fourth report to congress, EPA 816-R-09-001. U.S. EPA Office of Water, Washington 
Van Sickle J (2003) Analyzing correlations between stream and watershed attributes. J Am Water Resour Assoc 39:717-726

Vilsack T (2009) First public speech as Secretary of Agriculture, August 14, 2009, Seattle Washington. Available from http:// www.fs.fed.us/video/tidwell/vilsack.pdf. Accessed February 2011

Ward MH, de Kok TH, Levallois P, Brender J, Gulis G, Nolan BT, VanDerslice J (2005) Workgroup report: drinkingwater nitrate and health-recent findings and research needs. Environ Health Persp 113:1607-1614

Wickham JD, Riitters KH, Wade TG, Jones KB (2005) Evaluating the relative roles of ecological regions and land- cover composition for guiding establishment of nutrient criteria. Landscape Ecol 20:791-798

Wickham JD, Nash MS, Wade TG, Currey L (2006) Statewide empirical modeling of bacterial contamination of surface waters. J Am Water Resour Assoc 42:583-591

Wickham JD, Riitters KH, Wade TG, Homer C (2008) Temporal change in fragmentation of continental US forests. Landscape Ecol 23:891-898

Wickham JD, Riitters KH, Wade TG, Vogt P (2010) A national assessment of green infrastructure and change for the conterminous United Sates using morphological image processing. Landsc Urban Plan 94:186-195 